Article

\title{
Mind the Gap Between Higher Education and the Labour Market for Students with a Disability in the Netherlands: A Research Agenda
}

\author{
Marjolein Büscher-Touwen ${ }^{1,2, *}$, Marian de Groot ${ }^{1,2}$ and Lineke van Hal ${ }^{3}$ \\ ${ }^{1}$ Expert Centre Handicap + Studie, 5211 AP s-Hertogenbosch, The Netherlands; E-Mails: marjolein.buscher@handicap- \\ studie.nl (M. B.-T.), marian.degroot@handicap-studie.nl (M.d.G.) \\ ${ }^{2}$ CINOP, 5211 AP s-Hertogenbosch, The Netherlands \\ ${ }^{3}$ Verwey-Jonker Institute, 3512 HG Utrecht, The Netherlands; E-Mail: LvanHal@verwey-jonker.nl \\ * Corresponding author
}

Submitted: 29 June 2018 | Accepted: 28 August 2018 | Published: 6 December 2018

\begin{abstract}
The transition from higher education to the labour market is experienced as difficult by students with a disability. This gap between higher education and the labour market has tangible consequences for the participation of (young) people with a disability. Research shows that these students have a higher unemployment rate. This article addresses this gap by studying existing research data and by exploring experiences of students with a disability and other stakeholders as collected by the Dutch expert centre Handicap + Studie. We focus on the perspectives and responsibilities of the different parties involved: educational institutions, employers, municipalities, ministries and students with a disability. With this exercise, we want to contribute to putting this 'gap' and its stakeholders on the research agenda, arguing that more in-depth research on the transition from higher education to the labour market for students with a disability is needed. We will therefore conclude with themes that need to be researched in order to gain more knowledge for reducing the gap.
\end{abstract}

\section{Keywords}

disability; higher education; labour market transition; stakeholders; unemployment

\section{Issue}

This article is part of the issue "Students with Disabilities in Higher Education", edited by Geert Van Hove (Ghent University, Belgium/VU Amsterdam, The Netherlands), Minne Bakker (VU Amsterdam, The Netherlands) and Alice Schippers (Disability Studies in the Netherlands/VU Amsterdam, The Netherlands).

(C) 2018 by the authors; licensee Cogitatio (Lisbon, Portugal). This article is licensed under a Creative Commons Attribution 4.0 International License (CC BY).

\section{Introduction}

Work is an important way to participate in society, to be economically self-sufficient and to give one's life a sense of purpose. However, participation in the labour market turns out to be more difficult if you have to deal with disabilities such as a chronic illness, physical disability, autism or Attention Deficit Hyperactivity Disorder (ADHD). This holds true even if you are young and have a good educational qualification (university, university of applied sciences). Indeed, highly educated young people with a disability experience obstacles in their transition from studying to employment. This has two consequences: on the one hand young people do not receive the opportunities they need, and on the other hand society takes measures that do not really contribute to a solution. How should we understand this gap between higher education and the labour market? And what should be done to bridge this gap? These are the questions we want to discuss. More specifically, we concentrate on setting a research agenda focussed on the transition from higher education to the labour market for young people with a disability aged 18 to 27 .

\section{Approach}

This article is based on an explorative study of perspectives and experiences of different stakeholders in- 
volved in the transition from education to the labour market. The exploration is based on individual interviews and group discussions held by the Dutch expert centre Handicap + Studie. Participants were large municipalities (7); the Ministry of Education, Culture and Science (OCW); the Ministry of Social Affairs and Employment (SZW); educational institutions (10 universities, 15 universities of applied sciences); students and alumni with a disability (30); specialised intermediary agencies for young people with a disability (4); trade unions (2); National Think Tank 2017; politicians (5); and interest groups (5). From all interviews and group discussions, reports were made and shared with the informants.

The exploration started in 2014 with interviewing the Employee Insurance Agency (UWV), representatives of educational institutions, municipalities, specialised vocational rehabilitation agencies and employers. The goal of these conversations was to detect issues and bottlenecks regarding the transition from higher education to the labour market of students with disabilities. These issues were validated and further explored during group discussions in 2015 around the theme of internship and work of students with disabilities. In these well-visited meetings (135 participants), there was a shared recognition of bottlenecks. Subsequently, the exploration was deepened by interviewing labour unions, a group of students with disabilities and national ministries. In this process, bottlenecks were validated and insight grew in the (possible) roles and positions of various stakeholders.

In 2017 the reports of aforementioned meetings were thematically categorised within a project group, with experts on (higher) education and disability, quality of labour participation and sustainable employment. Categorisations were based on common types of bottlenecks and roles and responsibilities of stakeholders. The preliminary categorisation was presented to various stakeholders from which the educational institutions, alumni with a disability, student trade unions and labour unions confirmed the analyses of bottlenecks and stakeholder responsibilities. In 2018 new group discussions were held in order to explore changes in transitions issues, to deepen our understanding of existing bottlenecks and to explore possible solutions. In these meetings (3) the categorised bottlenecks were discussed and broadly recognised by the (150) participants.

Based on the aforementioned practical explorations, in this article we describe the roles of the various stakeholders, the categorisation of bottlenecks and relevant issues for further research. The roles and bottlenecks are illustrated by quotes from individual interviews and group discussions.

\section{Dutch Context}

Thirty percent of all students in Dutch higher education state that they themselves study with a disability, and $10 \%$ of all students experience obstacles as a result (Van den Broek, Muskens, \& Winkels, 2013). At the same time, the employment rate of people with a disability in the Netherlands is twice as low as that of people without a disability (Statistics Netherlands [CBS], 2015, 2016). Recent figures from CBS on the Dutch labour market indicate that $15 \%$ of all employees feel slightly impeded in carrying out their work by a long-term illness, affliction or handicap and $3 \%$ feel strongly impeded in their work. However, employees aged 18 to 27, who are the focus of this article, feel less impeded by a disability than older employees aged 55 to 65 . Women experience impediments more often than men and this difference is even more marked among younger employees (Van den Berg, Dirven, \& Souren, 2018).

"The Europe 2020 strategy objective aims at reaching $75 \%$ employment rate in the European Union (EU) for people with a disability" (European Disability Forum, 2018). However, the employment rate of people with basic activity difficulties and/or longstanding health problems in the EU-28 was $47.3 \%$, almost twenty percentage points below that of people without such difficulties. At country level, the highest gaps in employment rate were observed in the Netherlands $(43 \%$ and $80 \%$ respectively) and Hungary (24\% and $61 \%)$, with differences of more than thirty seven percentage points between the groups. This contrasts sharply with the situation in Luxembourg, where the smallest variation (two percentage points) was observed (Eurostat, 2011).

These figures show that the Netherlands, in comparison to other countries, is falling behind in terms of the employment rate of people with a disability and this is a cause for concern.

\section{Patterns and Gaps in the Netherlands}

There is currently not enough information available about the situation of more highly educated young people with a disability who are transitioning from higher education to the labour market. The first indications of difficult access to the labour market can already been seen during their studies. Some of the students with a disability, for instance, do not manage to find suitable internships. This is often due to two causes: 1 ) conversations with students and supervisors show that students often find it difficult to communicate their disability, for instance because they fear not being accepted for the internship; 2) furthermore, employers still struggle to see the person behind the disability, do not know how to respond to this issue and therefore offer only limited support. Various organisations that provide work-related support to people with a disability confirm this problem and aim to tackle it. In cases where completing an internship constitutes part of the final attainment level of the degree programme and it proves impossible to complete this component, this means that these students leave the programme without a degree certificate, which makes it difficult to find a job. Sometimes students manage to graduate without an internship or other work experience. Due to a limited ability to handle workloads, it is not al- 
ways possible to combine work and studies. However, work experience is often an important element on the curriculum vitae (CV) presented to employers in order to have a better chance of a job.

In the Netherlands, the education process culminates in a degree certificate. After completion of the degree programme, the education system ceases to provide support. Once they have a degree certificate in their pocket, young people are left to their own devices. This includes those young people who require support in finding their niche in the labour market. Paradoxically enough, the fact that they stand alone seems to be related to the large number of involved parties who play a role regarding the education, work and income of young people with a disability: all of these parties work along separate tracks.

\section{Stakeholders}

Various parties are involved in the transition of young people with a disability from education to the labour market. The various parties and their roles and responsibilities are set out below, together with their perspectives on the issue.

\subsection{Higher Education Institutions}

The higher education institutions are responsible for their students until they have completed their degree programme with a degree certificate. Generally speaking, the educational institutions assume that students take steps towards and into the labour market independently. The institutions put their focus on a good education and on supplying qualified, independent and responsible students to a certain specialist field. This is revealed by conversations conducted by Handicap + Studie with the OCW and the experiences of professionals at the educational institutions. As a consequence, there is no structural attention given to preparing young people with a disability for the labour market and helping them make the transition.

\subsection{Municipalities}

The basic principle applied by the Dutch government is full participation: everyone takes part. This means that no person should be left behind, that people help each other, and support is offered to vulnerable people so that they can as much as possible participate in society as well. However, the municipalities that put this principle into practice are currently placing their main focus on youth unemployment among less well-educated young people with a disability and not, or less, on more highly educated young people with a disability. This is revealed by conversations with seven large municipalities. The alderman for economic affairs and education from Rotterdam stated: "We have to deal with scarce resources and our emphasis in policy is on young people without a basic qualifica- tion in the poor neighbourhoods". A policy advisor from Eindhoven underlined this vision: "Our focus is on youth employment and especially on young people without a basic qualification".

\subsection{Ministries}

The OCW states that the higher education system is responsible for a good education up to and including the degree certificate. Its policies devote little or no attention to preparing for and transitioning to the labour market. As the head of policy advisors in Higher Education expressed: "The transition to the labour market for students with a disability should have more attention. That is according to us the responsibility of the Ministry of Social Affairs and Employment". In 2017, a number of young people's organisations found that too many students feel insufficiently prepared for the labour market (ROA, 2017).

The SZW is responsible for employment, integration, reintegration and participation. Young people with a disability first need to be without work before a safety net comes into operation. These persons can then apply to the municipality for social benefit payments. The municipality must also help job seekers find work and prepare themselves accordingly. People who are expected never to be able to earn the minimum wage due to their illness or handicap are entitled to invalidity benefits. The Social Affairs and Employment Inspectorate has conducted research into the support offered by municipalities to young people with a work-limiting disability. One of the conclusions is that some of the young people are not on the radar of the municipalities. This principally involves young people who do not (yet) receive any benefit payments and young people who lose their job. A total of $6 \%$ of all municipalities state that they do not have a clear picture of this group (Social Affairs and Employment Inspectorate, 2016).

The Ministry of Health, Welfare and Sport is the umbrella ministry for disability policy and therefore also for the implementation of the United Nations Convention on the Rights of Persons with Disabilities (UNCRPD). This was ratified in the Netherlands in 2016 and states:

States Parties recognize the right of persons with disabilities to work, on an equal basis with others; this includes the right to the opportunity to gain a living by work freely chosen or accepted in a labour market and work environment that is open, inclusive and accessible to persons with disabilities. (United Nations [UN], 2016)

The UNCRPD is based on inclusion, personal autonomy and full participation. It requires organisations to think proactively about the inclusion of people with a disability so that they can participate in all areas of society and in all processes. 


\subsection{Employers}

Some employers take on people with a disability and have a corresponding policy. They are required to carry out appropriate adjustments in line with the Equal Treatment of Disabled and Chronically III People Act. To provide some examples, many employers operate inclusive policies for employing and retaining people with a disability, such as Philips, Shell, ABN-AMRO, PWC and many companies in the small and medium enterprises (SME) sector. However, many employers remain reluctant to take on employees with a disability or state that they are unable to offer any suitable jobs (National Think Tank, 2017). For example: employers are afraid that young people from this target group, because of their vulnerable health, will fall out sooner by sickness and that they have to pay them for two years because of legislation. Employers also see practical barriers like difficulties in extra guidance. There is ignorance about how to get in contact with young people with work limitations. Moreover, employers are hindered by the procedures hassle (National Think Tank, 2017, p. 15). See also the paragraph on changed legislation and regulations in section 5 .

\subsection{Students with a Disability}

In addition to the responsibilities of organisations, students with a disability also bear their own responsibility to prepare for and transition to the labour market. These young people themselves need to state that they experience obstacles and require support. It is also important that they participate actively in offered activities, such as job application workshops, in order to prepare as thoroughly as possible for the transition to the labour market.

What do young people with a disability themselves say about their preparation for-and access to-the labour market? A few quotes from a meeting, in October 2017, between Handicap + Studie and the trade union CNV Jongeren follow:

As a disabled employee, I have to work harder.

I need to prove myself more.

My degree programme should have devoted more attention to career orientation with a disability.

Due to my functional disability, I experience additional stress about entering the labour market.

These quotes show that young people with a disability experience more difficulties in preparing for and accessing the labour market than young people without a disability. They indicate that they have the feeling they need to prove themselves more by working harder, and also that they feel insufficiently equipped for entering the labour market with disabilities. Research by Gerritsen, Van Hal, Meesters, Van Bodegom and Verharen (2018) shows that young people with a disability want to be seen as 'normal', but they realise that they require support to a certain extent. They appreciate support persons who put themselves in the other person's shoes in practical terms and who see both disabilities and possibilities. However, young people are often unsure about their prospects, including those on the labour market, and this in turn influences the expectations they have of themselves. The transition from education to work is experienced as difficult.

What are the explanations for this difficult transition as described above?

\section{Possible Causes of the Low Labour Force Participation Rate}

\subsection{Changed Legislation and Regulations}

The principle of the Participation Act is for as many people as possible to work in normal jobs for normal employers. Since 1st January 2015, municipalities are responsible for people with a functional disability who are able to work (people with an ability to work). As a result, young persons with a disability but also an ability to work have been barred from the WAJONG - the Disability Act for young people-benefit payment system as of 1st January 2015. This has made it all the more important for them to find work, but not all jobs are suitable for more highly educated young people with a disability.

Employers, too, are reluctant to take on employees with a disability. The majority of the more highly educated young people with a disability do not come under the definition of the target group register, a national register containing everyone who comes under the Jobs Agreement. The Jobs Agreement between the government and employers means that both parties have an obligation to create jobs for people with an illness or disability. A person receives an indication for the Jobs Agreement (and thus inclusion in the target group register) if they are unable to earn the minimum wage due to an illness or disability (UWV, 2018).

This means that in terms of the Jobs Agreement, they do not offer any added value to employers. It is attractive for employers to employ persons from the target group register because they can take advantages of schemes such as wage subsidies, a no-risk insurance policy and a job coach. In addition, these employees count towards the total laid down in the Jobs Agreement. Due to their level of education, more highly educated young people with a disability can be considered for higher and betterpaid positions. As a result, they are usually not eligible for an indication unless they have a very serious disability. However, this means that the great majority of the more highly educated fall between two stools in this respect. 


\subsection{No Policy or Monitoring Regarding the Transition to Work}

Most higher education institutions do not have a policy on helping students with a disability to get internships and jobs. Handicap + Studie carried out interviews at 25 universities and universities of applied sciences, asking whether attention is given to preparing students with a disability for the labour market. This reveals that the institutions devote limited and incidental attention to (specific) preparation for the internship and the labour market. As a student counsellor stated:

The priority in my work is on a good start of the study and the first couple of years of the student with a disability. Our university offers career guidance, but there is a lack of knowledge about the transition to the labour market for students with a disability.

Limited or incidental attention often involves ad-hoc activities at a programme or faculty level on the initiative of individual staff members. Examples include job application and networking workshops, buddy projects for students with autism and a priority internship for students with a disability (see section 6.4 on good practices below). Students with a disability are not monitored following completion of their studies or if they drop out before graduation. As a result, higher education institutions have no accurate picture of how these students are doing, nor do they have solid figures. Once the students have completed their studies, the institutions lose contact with them. In this respect, they have now fallen into the 'gap' as well.

These young people require appropriate support during the move from education to the labour market. In this important transitional phase (the final year of studies and the first year after graduation) the main issues are finding an internship, graduating, seeking a job, applying and then starting work and holding on to your job. In conclusion, the education sector often devotes no attention to what comes after the completion of the degree programme. However, the education sector is already familiar with these young people and their studies are actually the time when attention should already be given to facilitating the next step after graduation. Young people can also indicate in the annual National Student Survey (NSE) how they feel about how their institution has prepared them for their further professional career. There are no specific figures available for students with a disability, but the figures for all students (Holzmann \& Berger, 2017) for 2017 show that the average satisfaction score for preparations for a professional career was 3.52 (on a five-point scale), but this differs widely between institutions: students at universities of applied sciences are more satisfied than students at research universities. Within this theme, they are least satisfied with the contact with the professional field (3.43). The theme of internships as part of the programme is assigned the second-worst score: students are dissatisfied with how their institutions prepare them for the internship (3.14), while they are a little more positive about support and supervision during the internship (3.35). They are much more positive about the experience gained during internships (3.94).

\subsection{No Ownership of the Problem}

Consultations with the OCW, the SZW and UWV'S Social Medical Affairs division (SMZ) have made clear that there is currently not enough collaboration between educational institutions, municipalities and employers to prevent young people with a disability from falling through the net and/or becoming unemployed. No single party has assumed ownership of the problem-it seems that the responsibility of the education system stops when students leave the institution and the responsibility of the SZW and of the municipality only begins when a person is sitting at home and applies for a benefit. As an employee of the Ministry of OCW expressed: "Transition to the labour market is an important issue. In our opinion this is the responsibility of the SZW and the municipalities". Quotation of a policy advisor of a municipality: "We have to prioritize. Therefore, our focus is on the young people with very little chances in life. So, we cannot give attention to high-educated young people with a disability". There are no incentives provided to employers, they are simply appealed to in moral terms. There is no legislation regarding support and integration in the labour market for more highly educated young people.

\subsection{Stigmatisation and Prejudices}

People with a work-limiting disability need to draw attention to their limitations in order to be eligible for support by society. On the other hand, processes of integration in the labour market often devote little attention to finding and retaining work when you have a disability.

Previous research into labour market reintegration of adults with work-limiting disabilities (Van Hal, Meershoek, Nijhuis, \& Horstman, 2012, 2013) shows that support schemes often devote attention exclusively to possibilities. As a result, it is insufficiently clear to both job seekers with a disability and to employers how someone can best work on the basis of both their possibilities and their disability.

Many employers (49\%) state that they have no suitable jobs for people with a work-limiting disability. Moreover, they often have prejudices about employees with a disability (Netherlands Institute for Human Rights, 2013), for instance that these employees are more frequently absent, require a lot of support, and are burdensome and expensive. This is also due to unfamiliarity with the target group and the lack of support possibilities. Consequently, they are reluctant to take on young people with a disability. One of the employers explained: 
I didn't realise that we also can hire high-educated young people with a disability. Our focus is on the target group register, but we also need high-educated young people with a disability, so this is a new opportunity for us.

Another employer mentioned:

Every time an employee with a new disability (for example, autism, a physical disability or an hearing impairment) start working at our company, the employee faces all kinds of problems and we need time to make adjustments to the working procedures to include the employee.

The social costs of attention, interventions and extra efforts on the part of the parties involved should however be weighed up against the benefits for society when young people enter work, pay taxes and no longer require social benefit payments (Bureau Doet, 2017). Participation promotes the sense of inclusion and leads to improved health. As the UN formulated it:

Although there is no universally agreed definition or benchmark for social exclusion, lack of participation in society is at the heart of nearly all definitions put forth by scholars, government bodies, non-governmental organizations and others. Overall, social exclusion describes a state in which individuals are unable to participate fully in economic, social, political and cultural life, as well as the process leading to and sustaining such a state. (UN, 2016)

Some educational institutions that do devote specific intention to preparing young people with a disability for the labour market have launched initiatives to help them make the transition. These can be regarded as good practices:

- Each year, Radboud University Nijmegen organises a career week in which a workshop for students with a disability is a standard part of the programme.

- Fontys University of Applied Sciences started a pilot with job coaches to support 15 students with (characteristics of) autism from their internship up to and including the start of their first job. By taking part in the pilot, students were less likely to fall behind, and they found a more suitable job. The pilot was conducted in cooperation with the municipality of Eindhoven, job coaches from 'Autismepunt' and employers. They gained insights into the success and failure factors of the method (qualitative) and funding options for an integrated approach.

- Hanze University of Applied Sciences' School of Nursing started priority internships for students with a disability. The career centre ensures that these students are given priority at one of the internship addresses. Corresponding agreements have been made with the care institutions in question.

- The executive Board of Fontys University of Applied Sciences indicated at a meeting on the transition from higher education to employment that her university feels responsibility for their students and alumni until they are landed on the labour market or in further education.

- Delft University of Technology offers a Job Search workshop for students with an Autism Spectrum Disorder. They offer: a preliminary interview with a student career advisor; four theme-related meetings of 2.5 hours each in a group with a maximum of six students (theme 1: self-analysis, qualities and interests; theme 2: CV guidelines; theme 3 : motivation letter guidelines; theme 4 : preparation for the job application interview); concluding interview and follow-up steps, possibly with external parties such as a job coach from the municipality.

- The University of Groningen organised a workshop for students with a disability about job applications and drawing up a job application letter. They also provided this workshop to staff of the Student Service Centre and of Career Services. These staff members advise students on job applications. The programme was organised by two student counsellors and two student employees of Career Services. The training was provided by an alumnus with practical expertise in the field who also provides similar training sessions to the Eye Association Netherlands (a patient association for people with a visual disability). The training was widely advertised, with an announcement being sent to all students who indicated when enrolling for the first year that they had a functional disability and would like to receive information about specific events for students with a functional disability. It was also posted on the Facebook page for students with a functional disability, and the student advisors were informed about the event.

\section{Conclusions}

This article explains how the labour market participation of more highly educated young people with a disability in the Netherlands is lagging behind compared to the participation of young people without a disability and why they often fall into the 'gap' between education and the labour market. The changing legislation and regulations do not work in favour of the more highly educated and of educational institutions and there is no policy on the transition to work for young people with a disability or for monitoring these young people. Furthermore, employers often have prejudices about taking on young people with a disability and see it as difficult to provide them with support. Results of the study by Nevala, Pehkonen, Koskela, Ruusuvuori and Anttila (2015) show 
that the key facilitators and barriers of employment were self-advocacy, support of the employer and community, amount of training and counselling, and flexibility of work schedules and work organisation. These topics should be taken into account when preparing students with a disability for the labour market. One final important conclusion is that there are many parties involved in the transition from education to the labour market for young people with a disability and (currently) insufficient collaboration between these parties; no party has taken ownership of the problem.

All these factors have consequences for the young people with a disability themselves, as well as for society. How can the gap between education and the labour market for these young people be closed? This requires further research on various themes.

\subsection{Themes for Further Research}

On the basis of the (limited) available research data and available experiences of students and other stakeholders, we recommend further research on the following themes:

\subsubsection{Preparation for the Labour Market in an} International Context

- What approach is taken in countries with a high level of participation by young people with a disability?

- What are the experiences of these young people themselves and of other stakeholders?

- How does this approach affect the transition of young people with a disability from education to the labour market?

According to Beyer and Beyer (2016, p. 68), the effectivity of employment support should be investigated. The conclusion of this review is that disabled people, governments, and taxpayers, are likely to benefit financially in the long-term from greater investment in inclusive employment:

When taken with the data on the gap in employment rates between disabled and non-disabled citizens, and the generally high levels of unemployment experienced by young people across the E.U., it seems clear that savings to taxpayers may be available if we invested in employment support that had evidence that it worked.

The Netherlands could learn from the United Kingdom in working towards inclusive higher education and using their suggestions for an inclusive approach (see Figure 1 below; Disabled Students Sector Leadership Group, 2017). This inclusive approach enables students with a disability to deliver to their full potential. It will also make a difference for employers and the society. It is an opportunity for higher education institutions to work in partnership with employers to improve the transition from education to the labour market.

\subsubsection{Responsibilities of Stakeholders}

- How do stakeholders see their responsibilities?

- What are the experiences of young people with a disability with regard to the various stakeholders?

- What is necessary for parties to work together on the basis of a shared responsibility to close the gap between education and the labour market for more highly educated young people with a disability?

Jordan, Schwartz and Mc-Gie-Richmond (2009) stated in their study about preparing teachers for inclusive classrooms:

We provide evidence to suggest that teachers' beliefs about disability and about their responsibilities for their students with disabilities and special educational needs may be part of a broader set of attitudes and beliefs about the nature of ability and about the nature of knowledge, knowing and how learning proceeds; that is, epistemological beliefs. The implications for these findings are considerable for teacher training and development. Little is known about how skills for effective inclusion are developed, or about how changes in teachers' beliefs about disability, ability and their epistemological beliefs may be reflected in changes in their practices.

How can beliefs about and attitudes of teachers towards students with disabilities be changed? How can skills for effective inclusion in education be developed?

7.1.3. Further Insight into the Situation of More Highly Educated Young People with a Disability in the Netherlands

- What is the size and composition of the group of more highly educated young people with a disability and what is the situation as regards their labour market participation?

- What are the experiences and needs of the young people themselves?

- What are success factors for labour market participation?

Once the proposed research has provided more knowledge, this could serve as basis for investigating the social costs and benefits of best practices that focus on bridging the transition from education to work.

With this article, the authors aim to help put the 'gap' and the various stakeholders on the research agenda and propose stones for bridging this gap. This has been done by arguing that more in-depth research into the transi- 


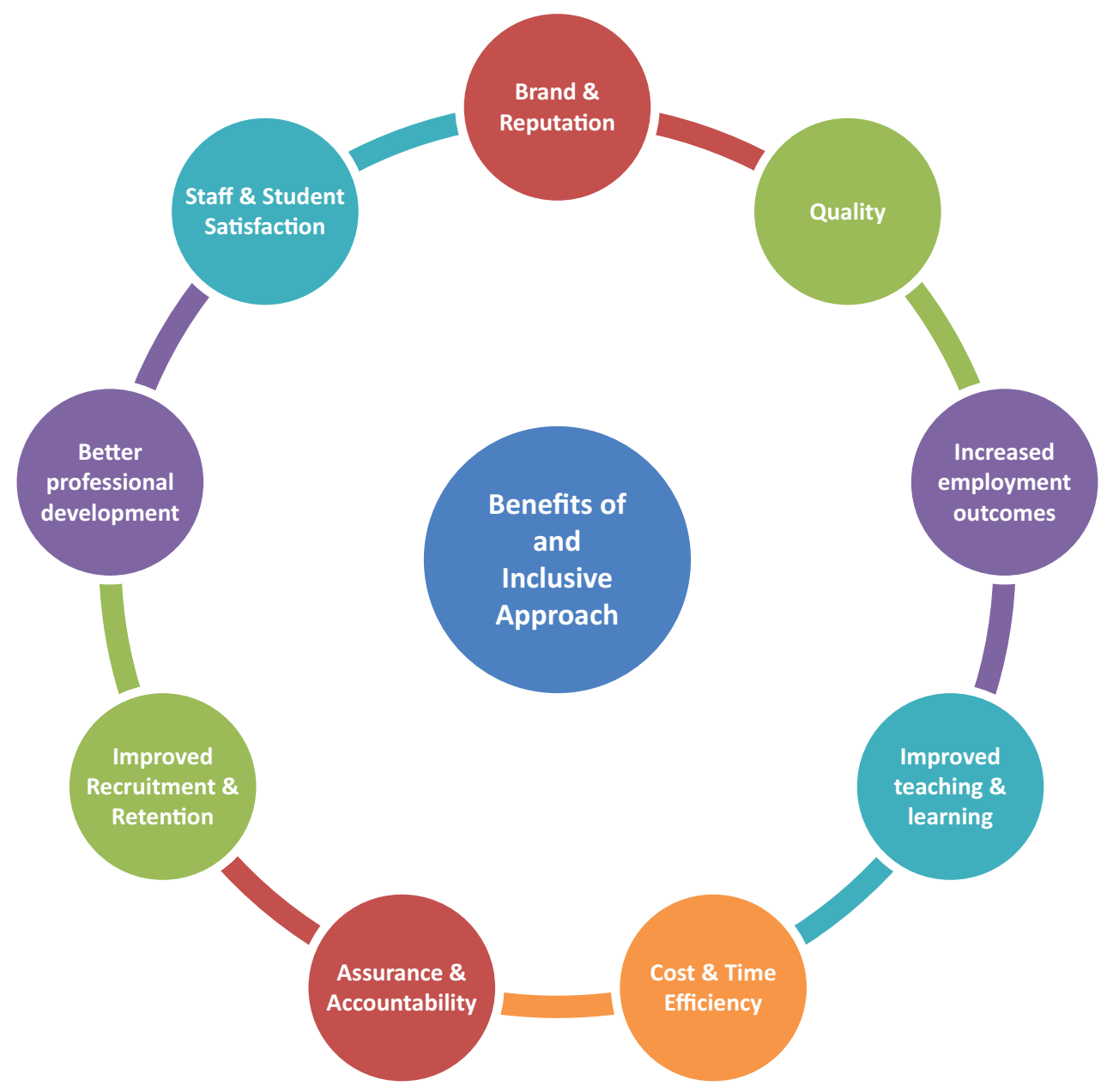

Figure 1. Benefits of an inclusive approach.

tion from education to the labour market for young people is required in order to narrow the 'gap'. Narrowing this 'gap' will benefit both the young people themselves and society as a whole.

\section{Conflict of Interests}

The authors declare no conflict of interests.

\section{References}

Beyer, S., \& Beyer, A. (2016). Economic impact of inclusion of disabled persons in the labour market. EASPDreport. Bern: Editions universitaires européennes.

Bureau Doet. (2017). Hoe zorgen voor een betere doorstroom naar werk voor studenten met een functiebeperking, maatschappelijke business case [How to ensure a better flow to work for students with a disability, social business case]. Arnhem: Bureau Doet.

Disabled Students Sector Leadership Group UK. (2017). Inclusive teaching and learning in Higher Education as a route to excellence. Disabled Students Sector Leadership Group UK. Retrieved from www.gov. uk/government/publications/inclusive-teaching-andlearning-in-higher-education
Employee Insurance Agency. (2018). Aanvraag beoordeling arbeidsvermogen [Request assessment working ability]. UWV. Retrieved from www.uwv.nl/parti culieren/arbeidsbeperkt/beoordeling-arbeidsvermo gen/mijn-aanvraag/detail/wat-is-een-indicatie-banen afspraak/wat-is-het-doelgroepregister

European Disability Forum. (2018). Employment. European Disability Forum. Retrieved from www.edf-feph. org/employment

Eurostat. (2011). Disability statistics: Labour market access. Eurostat. Retrieved from ec.europa.eu/ eurostat/statistics-explained/index.php?title=Disabil ity_statistics_-_labour_market_access

Gerritsen, M., Van Hal, L., Meesters, J., Van Bodegom, B., \& Verharen, L. (2018). Hoe past het? Een kwalitatieve analyse van narratieven van jongeren met een ondersteuningsbehoefte op het gebied van passend onderwijs en passende arbeid [How does it fit? A qualitative analysis of narratives of young people with a need for support and appropriate work]. Journal of Social Intervention: Theory and Practice, 27(1), 4-23.

Holzmann, M., \& Berger, B. (2017). Nationale Studentenenquête 2017. Het Landelijke tevredenheidsonderzoek onder studenten in het hoger onderwijs [Nation wide student survey 2017 . The national satisfaction 
survey among students in higher education]. Utrecht: Studiekeuze123.

Jordan, A., Schwartz, E., \& McGie-Richmond, D. (2009). Preparing teachers for inclusive classrooms. Teaching and Teacher Education, 25(4), 535-542.

National Think Tank. (2017). ledereen perspectief op werk [Everyone's perspective on work]. Nationale denktank. Retrieved from nationale-denktank.nl/wpcontent/uploads/2017/10/NDT-17-analyserapportDEF-1.pdf

Netherlands Institute for Human Rights. (2013). Literatuuronderzoek- De juiste persoon op de juiste plaats, de rol van stereotypering bij de toegang tot de arbeidsmarkt [Literature survey: The right person on the right place, the role of stereotyping at the access to the labour market]. College voor de rechten van de mens. Retrieved from www.mensenrechten.nl/ publicaties/detail/18402

Nevala, N., Pehkonen, I., Koskela, I., Ruusuvuori, J., \& Anttila, H. (2015). Workplace accommodation among persons with disabilities: A systematic review of its effectiveness and barriers or facilitators. Journal of Occupational Rehabilitation, 25(2), 432-448.

ROA. (2017). Schoolverlaters tussen onderwijs en arbeidsmarkt 2016 [School-leavers between education and labour market]. ROA. Retrieved from roa.sbe. maastrichtuniversity. $\mathrm{nl} / \mathrm{p} \mathrm{p}=12048$

Social Affairs and Employment Inspectorate. (2016). Als je ze loslaat, ben je ze kwijt [If you let them go, you lose them]. Inspectie SZW. Retrieved from www. inspectieszw.nl/publicaties/rapporten/2016/10/15/ als-je-ze-loslaat-ben-je-ze-kwijt

Statistics Netherlands. (2015). Eén op de drie arbeidsge- handicapten heeft betaald werk [One in three people with working disabilities has paid work]. CBS. Retrieved from www.cbs.nl/nl-nl/nieuws/2015/05/eenop-de-drie-arbeidsgehandicapten-heeft-betaald-werk

Statistics Netherlands. (2016). Met arbeidshandicap vaak niet actief op de arbeidsmarkt [People with labor disabilities are often not active on the labour market]. CBS. Retrieved from www.cbs.nl/nlnl/nieuws/2016/29/met-arbeidshandicap-vaak-nietactief-op-arbeidsmarkt

United Nations. (2016). Leaving no one behind. Chapter 1: Identifying social inclusion and exclusion. United Nations. Retrieved from www.un.org/esa/ socdev/rwss/2016/chapter1.pdf

Van den Berg, H., Dirven, H-J., \& Souren, M. (2018). De arbeidsmarkt in cijfers 2017 [The labour market in figures 2017]. Den Haag: Centraal Bureau voor de Statistiek.

Van den Broek, A., Muskens, M., \& Winkels, J. (2013). Studeren met een functiebeperking 2012. De relatie tussen studievoortgang, studieuitval en het gebruik van voorzieningen [Studying with a disability 2012. The relationship between study progress, dropout out of study and the use of provisions]. Nijmegen: ResearchNed/ITS.

Van Hal, L. B., Meershoek, A., Nijhuis, F., \& Horstman K. (2012). The 'empowered client' in vocational rehabilitation: The excluding impact of inclusive strategies. Health Care Analysis, 20(3), 213-230.

Van Hal, L. B., Meershoek, A., Nijhuis, F., \& Horstman, K. (2013). Disembodied abilities: Sick role and participation in 'activating' return-to-work practices. Social Science \& Medicine, 96, 9-16.

\section{About the Authors}

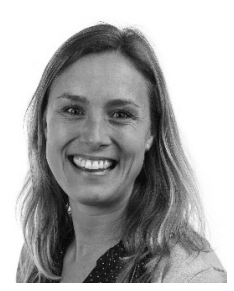

Marjolein Büscher-Touwen is consultant at Expert Centre Handicap + Studie. She stimulates and supports educational institutions in the development of inclusive education. She graduated as a communication scientist and worked at the central counselling department of the VU University Amsterdam for several years having different roles: disability advisor, career counsellor and project manager. She also lived in Mozambique and was involved in projects of Handicap International and a local literacy organisation for children.

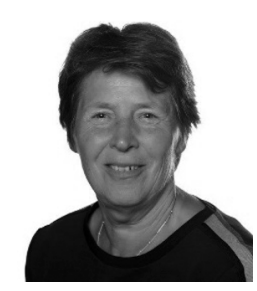

Marian de Groot is Director of the Dutch Expert Centre Handicap + Studie. She studied psychology and managing of change in organisations. The focus in her work is on inclusion of students with a disability in (higher) education and the labour market.

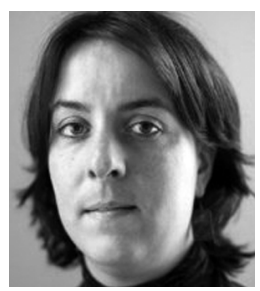

Lineke van Hal, PhD, is a Senior Researcher at the Verwey-Jonker Institute, the Netherlands. Trained as a medical anthropologist, she conducts scientific research on social issues such as participation, work and youth (care). In her work she pays attention to perspectives of citizens, 'clients' and professionals to study from a multiple perspective what happens in practice. 